\title{
GOYA LOPES - TRAJETÓRIA DE UMA CRIADORA
}

GOYA LOPES - Journey of a Creator

\section{Goya Lopes}

Designer Têxtil e Artista Plástica, formada em Belas Artes pela UFBA, com

Especialização na Universidade Internacional de Artes de Florença goyalopes@gmail.com 


\section{GOYA LOPES - TRAJETÓRIA DE UMA CRIADORA}

GOYA LOPES - Journey of a Creator

Goya Lopes

\section{Resumo}

$\mathrm{O}$ artigo apresenta a criação de uma vertente da moda e decoração com a finalidade de atender a demanda de um mercado que sonhava com um produto com identidade cultural, vinculado à matriz africana e/ou afro-brasileira. Trata-se de texto biográfico ilustrado com fotos $\mathrm{e}$ desenhos da produção artística da autora. Foram adotadas três etapas: motivação da autora desde a descoberta, quando criança, de que tinha uma maneira diferente de desenhar; formação como artista plástica e designer e a estratégia de ser empresária, para estar no mercado e poder desenvolver um padrão de estamparia que tivesse personalidade própria. A contribuição desse trabalho pioneiro da moda afrobrasileira abriu caminhos para a discussão de um novo contexto ainda não muito discutido no campo da moda. Abordagem da experiência

da artista/designer/empresária Goya Lopes, um retrato de sua trajetória, formação e motivação ao longo de sua vida a fez construir esse trabalho autoral.

Palavras- chave: Motivação; Mercado Afro-brasileiro; Estamparia.

\begin{abstract}
This article presents the launching of a fashion and decoration trend linked to the African and/or Afro-Brazilian world. It was created with the purpose of meeting the market demands that envisioned a brand with this cultural identity. It is a biographical text illustrated with photos and drawings from the author's artistic production. The article is developed in three parts: the author's motivation since her childhood when she discovered she had a distinctive way of drawing; her training as a plastic artist and designer; and her entrepreneurship strategy to successfully develop and market a fabric stamping pattern with its own personality.The contribution of this AfroBrazilian pioneering design work paved the way for the examination of a new style that has not yet been sufficiently explored in the fashion world. The article reflects on the experience of Goya Lopes as an artist, designer and businesswoman, portraying her career and training, and also how the motivation throughout her life contributed to the creation of this authored work.
\end{abstract}

Keywords: Motivation; Afro-Brazilian Business; Fabric Stamping 


\section{MOTIVAÇÃO}

A motivação foi uma constante na minha vida ela sempre me direcionou e mostrou sinais que se transformaram em caminhos tanto na vida pessoal como na profissional. Sempre acreditei e amei o que fazia e tinha a certeza de que era a minha real natureza.

Aos sete anos fui morar por um ano na França. O meu pai, Hamilton Lopes que era engenheiro da Petrobrás, foi se especializar na École Nationale Superieure Du Pétrole do Istitut Français Du Pétrole de Paris e levou a família. Nós estudávamos na École Élémentaire nos arredores de Paris. Um dia a minha professora, uma pessoa sensível, chamou meus pais e disse que eu tinha um desenho diferente das outras crianças e, conversando com eles, mostrou-lhes a necessidade de motivar-me para o lado artístico. Meu pai comprou logo uma coleção do Louvre que eu tenho até hoje como talismã. Nas férias, viajamos pela Europa, foi uma viagem inesquecível.

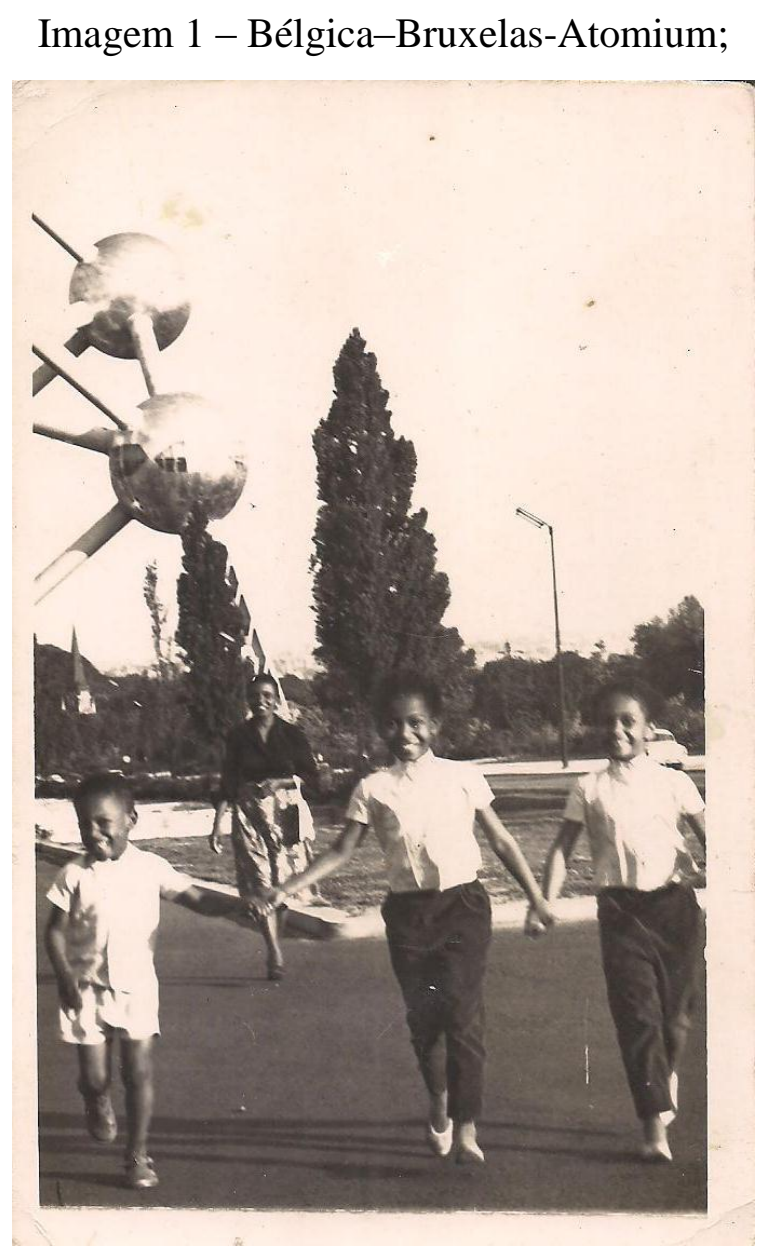

Fonte: acervo da autora. 
Aos onze anos, tive a primeira professora de artes, Marisa Gusmão, professora da Escola de Belas Artes da Bahia. Lá, nos intervalos de suas aulas, ela me ensinava desenho de observação e interpretação; assim fui apresentada pouco a pouco à cultura popular pelo olhar da professora Marisa, desenhando Ex-votos, Cerâmicas de Maragogipinho e peças da cultura popular.

\section{FORMAÇÃO}

Estudei pintura aos 15 anos na Panorama Galeria de Arte com Euler Cardoso, e ingressei na Escola de Belas Artes da UFBA-Universidade Federal da Bahia em 1972. As aulas de história da arte me deixavam curiosa e sedenta de saber mais, me impulsionando a fazer, em paralelo Artes Plásticas, o Curso de História na UCSALUniversidade Católica de Salvador,(que não foi concluído), por causa da viagem para a Itália, o que alimentou um antigo sonho de fazer arqueologia e pesquisar a África. Simultaneamente, eu desenvolvia a minha vida artística com exposições coletivas em Salvador e uma individual no Rio de Janeiro.

O Curso de História me levou a ser estagiária do IPAC - Instituto do Patrimônio Artístico e Cultural da Bahia. Inicialmente no setor de história e depois no Arca setor de restauração. Ao terminar o Curso de Artes Plásticas em 1976, tinha vários caminhos a seguir. Dentro de mim um grande desejo de estudar na França, na École de Beaux Arts, velho sonho meu e do meu saudoso pai, (falecido em 1968). O plano foi mudado após encontro com o italiano Gino Tapparelli que me orientou para concorrer a uma bolsa de estudo que o governo italiano oferecia para os artistas recém-formados no Brasil. Corri para me preparar, estudar italiano e consultar o professor de Estética Romano Galeffi que me orientou a estudar a profissão do futuro o Design. Sobre o design, na década de $70^{1}$ :

A partir de todo este impulso na década de 1970 os designers iniciaram um movimento que foi conhecido como New Design ou Anti-Design que propunha usar métodos artísticos, não mais dirigidos por projetos racionais, desfazendo os limites entre arte e design. As cadeiras de Stephan Wewerka são um emblema desta mudança anti-funcionalista. Sob o lema de "a forma segue a diversão" (form follows fun) e "menos é aborrecido" (less is bore) defendiam um design com maior função simbólica, com maior carga de humor e ironia, uso de elementos "kitch" (gosto popular e ordinário) e maior sensualidade.

\footnotetext{
${ }^{1}$ http://www.estagiodeartista.pro.br/artedu/histodesign/6_novodesign.htm
} 
Ganhei a bolsa de estudos em 1977 e iniciei a especialização em Design na Universitá Internazionalle Dell’Arte di Firenze.

\section{Imagem 2 - Firenze-Goya Lopes e Elisa Galeffi}

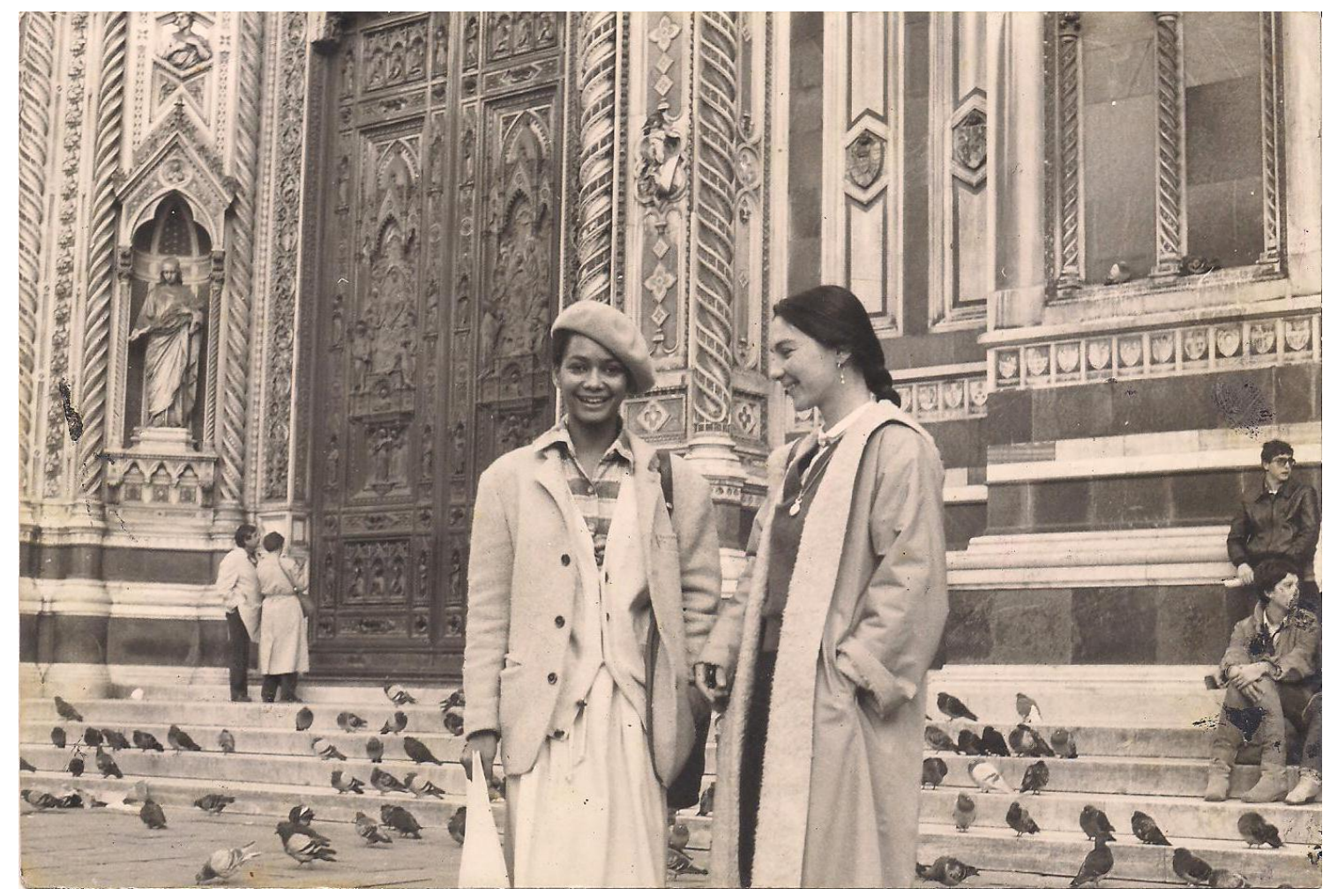

Fonte: acervo da autora

As matérias do curso eram Metodologia de Projeção; Processo Produtivo; Atividades Especiais e Experimentação. No projeto final do curso de especialização em Design fui orientada pelo professor de processo produtivo-têxtil designer de estofamento para trem, para desenvolver o trabalho sobre estampas e alinhar a minha veia artística ao design. Foram várias idas para ao Museo del Tessuto de Prato, que representa a importância da indústria têxtil Toscana. Aos poucos, foi sendo construída dentro de mim a vontade de fazer estamparia. Fiz outros cursos em Firenze, entre eles o de Litografia na Stamperia Santa Reparata e frequentei o Stúdio da designer Linda Ierimonti e a Stamperia Fiorentina, para aprender o processo de estamparia. Como artista plástica, fiz exposições coletivas e uma individual em Firenze.

Voltando da Itália em 1980, fiz alguns cursos de empreendedorismo, sendo o mais recente, em 2016, o da Endeavor, em parceria com o BID-Programa de Apoio a Empreendedores Afro-Brasileiros. De 2008 a 2009 fiz o curso de Design de Moda- 
IBModa pelo Projeto Estruturante Moda Design Bahia da SECTI-Secretaria de Ciência Tecnologia e Inovação da Bahia.

\section{ESTRATÉGIA}

No final dos anos 70, as estampas dos tecidos tiveram a influência da cultura étnica de todo o mundo, o que depois se tornou uma tendência mundial. Essa atmosfera crescia com vitalidade e a certeza de que seria referência por muitos anos. Simultaneamente, no Brasil, vale ressaltar que, citando Luz Garcia Neire (2012, p.233), "salpicaram iniciativas de construção de uma linguagem para o design têxtil que valorizasse nossa identidade cultural, como o caso de Casale, da Arte Nativa Aplicada ANA - e até mesmo de Zuzu Angel (1921-1976)".

No meu retorno da Itália em 1980, tinha em mente morar em São Paulo e um propósito definido: desenvolver estamparia étnica. Estive sempre alerta e sensível, percebendo e intuindo cada vez mais as solicitações dos processos criativos que aconteciam. A ANA-Arte Nativa Aplicada ${ }^{2}$ foi uma grande referência empreendedora para construção do meu objetivo: assisti às palestras feitas por Maria Henriqueta e visitei várias vezes a loja dela em São Paulo. Observava e me encantava com seus produtos, sonhava com uma marca que desenvolvesse a temática de matriz africana, mostrando a sua diáspora no Brasil, sua simplificação dos motivos naturais, e a sua essência que tanto mexe com o mundo.

Nessa fase, sobrevivia como freelancer, criava estampas para marcas de decoração, como Geada e Carol, Aziz Nader e a linha Madrigal da Alpargatas. Desenvolvi criações com referências na cultura popular brasileira para a linha Madrigal, toalhas, aventais, jogos americanos com estampas de carrancas, cerâmicas nordestinas e outros artesanatos.

\footnotetext{
2 Segundo Adélia Borges "Arte Nativa Aplicada já é velha de guerra. O mote para a sua criação, em 1976, foi a surpreendente constatação de Maria Henriqueta Gomes que todos os padrões produzidos pela indústria têxtil brasileira eram copiados de fora. Pesquisou com paciência a cerâmica, a cestaria, as esteiras, os desenhos em utensílios, a arte plumária e até pinturas corporais de cerca de 30 tribos" (BORGES, 1995).
} 
Imagem 3 - Carranca/Cerâmica Nordestina, Linha Madrigal;
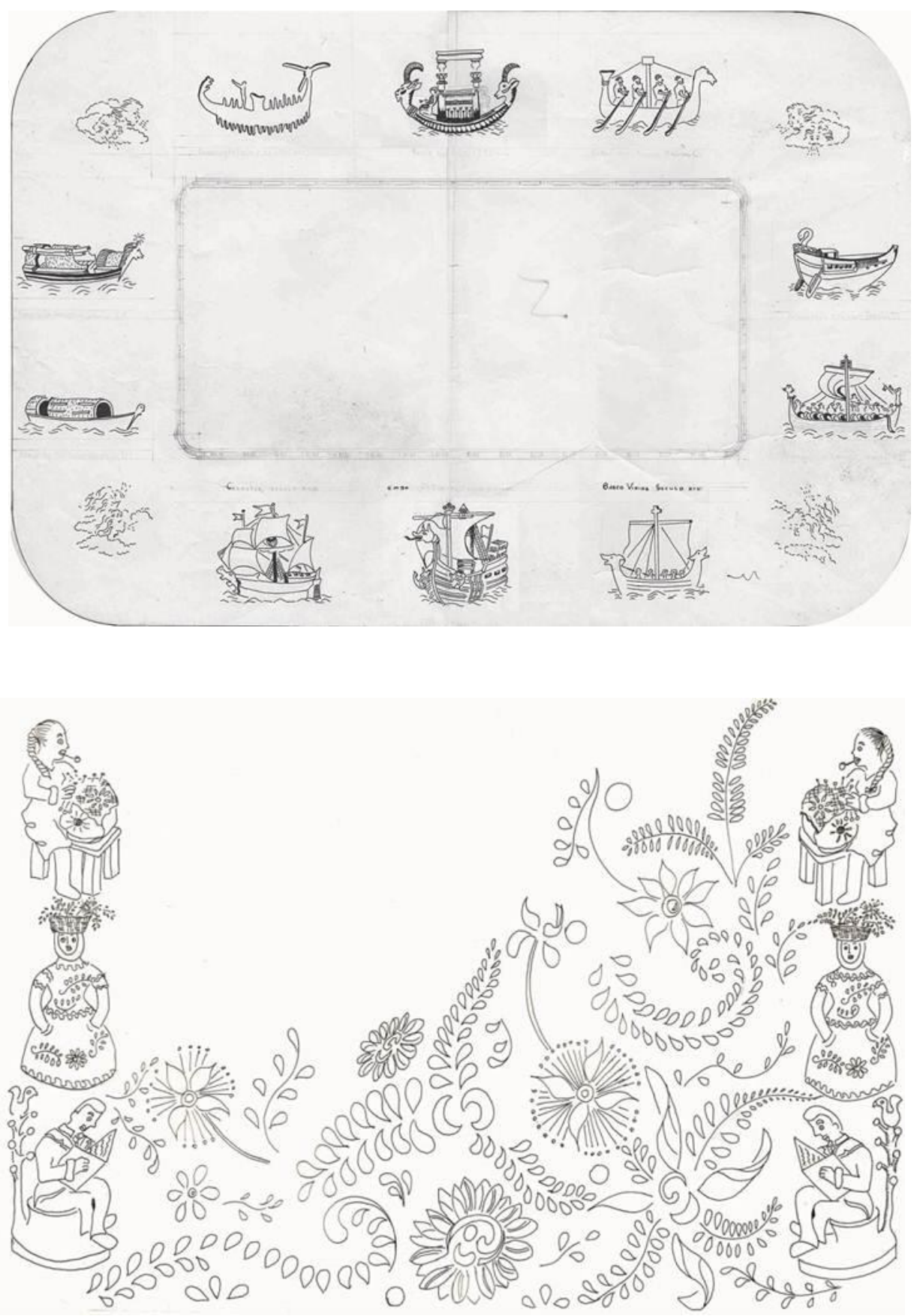

Fonte: acervo da autora.

Numa convenção, a Alpargatas encerrou a linha Madrigal, e eu tomei um novo rumo na minha vida: retornar para Salvador com o grande desafio de ser artista Idesigner/empresária. Ao retornar para Salvador em 1984, trabalhei para o Atelier Argolo, especializado em restauração. Ao mesmo tempo, durante um período, fiz parceria com Elisa Galeffi-artista plástica designer - que também tinha estudado na 
Universitá Internazionalle Dell'Art di Firenze. Desenvolvemos estampas com a técnica de molde vazado em duplex, seguimos depois caminhos diferentes. Elisa foi desenvolver uma linha de Mandalas, e eu fui aos poucos pensando e criando o conceito do que seria a sonhada marca étnica.

Em 1986, iniciei a empresa Didara (o que é bom em Iorubá) e o projeto da construção de um padrão. Transformei a loja, aberta em 1987 no Centro Antigo de Salvador, como laboratório para interagir com turistas, público-alvo inicial, interessados na cultura baiana, e, assim poderia criar e desenvolver estampas, sem ficar presa a tendências da moda. Procurei, como artista plástica e designer, ser observadora, curiosa, estudiosa do conteúdo afro-brasileiro, buscando um trabalho sistemático, objetivo e constante, como em qualquer área do conhecimento. Encontrei na moda e decoração o suporte ideal para o conteúdo desejado. Ali contava a nossa história, falava da nossa gente, do nosso cotidiano, da nossa luta, cor local e dos ancestrais.

Para a construção desse processo de constante experimentação, era necessário trabalhar, inicialmente, a estampa localizada, pois os vestidos e camisetas tinham que passar a sensação de quadros. Depois, utilizei as estampas com rapport. A proposta de serem criações artísticas e a sensação de terem sido feitos à mão foram fundamentais, tanto quanto a utilização das mesmas cores (amarelo, vermelho, azul, royal, preto e branco) durante os primeiros cinco anos, bem como os experimentos de cores quentes e frias. A questão da cor é muito forte, ela é o fator que mais sobressai numa estampa, daí a necessidade dessa estratégia. A utilização da figura e fundo nas estampas criou uma identidade nas formas. A roupa tem um corte reto, onde o destaque é dado à estampa. Um caftan, por exemplo, libera o corpo, cobrindo com cores e temas. Há um conceito simples e marcante na forma como a peça foi cortada e estruturada.

A estratégia de ser empresária do meu projeto de design ajudou muito, pois sabia que o processo era de longo prazo, o que dificultaria se eu não fosse dona do meu próprio negócio. Tinha liberdade e a coragem de criar. Era necessário uma consciência da própria capacidade, para avançar fronteiras e criar estampas que tivessem personalidade própria e fossem identificáveis. Pouco a pouco foi sendo agregadas, ao processo criativo, características culturais afro-brasileiras, fatos vivenciados, percebidos e intuídos, observados por mim o que resultou numa marca contadora de história da cultura afro brasileira. 
Imagem 4 - Quituteira-referência histórica Debret-Bubu estampado

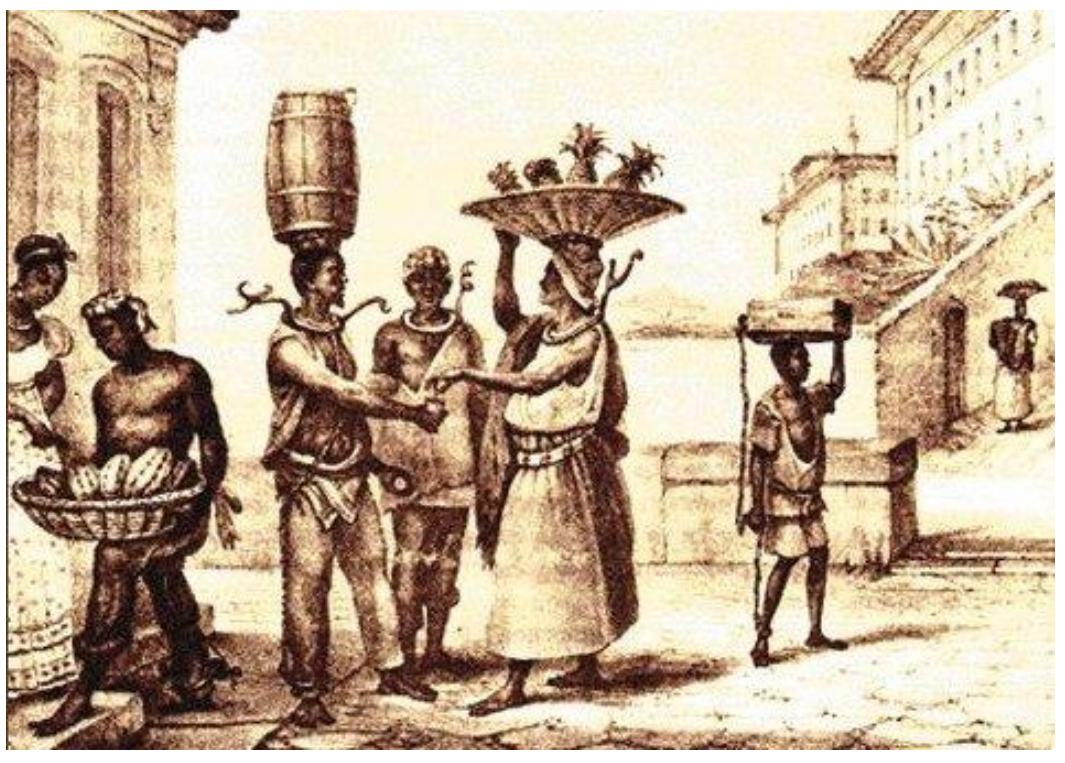

Fonte: Acervo autora

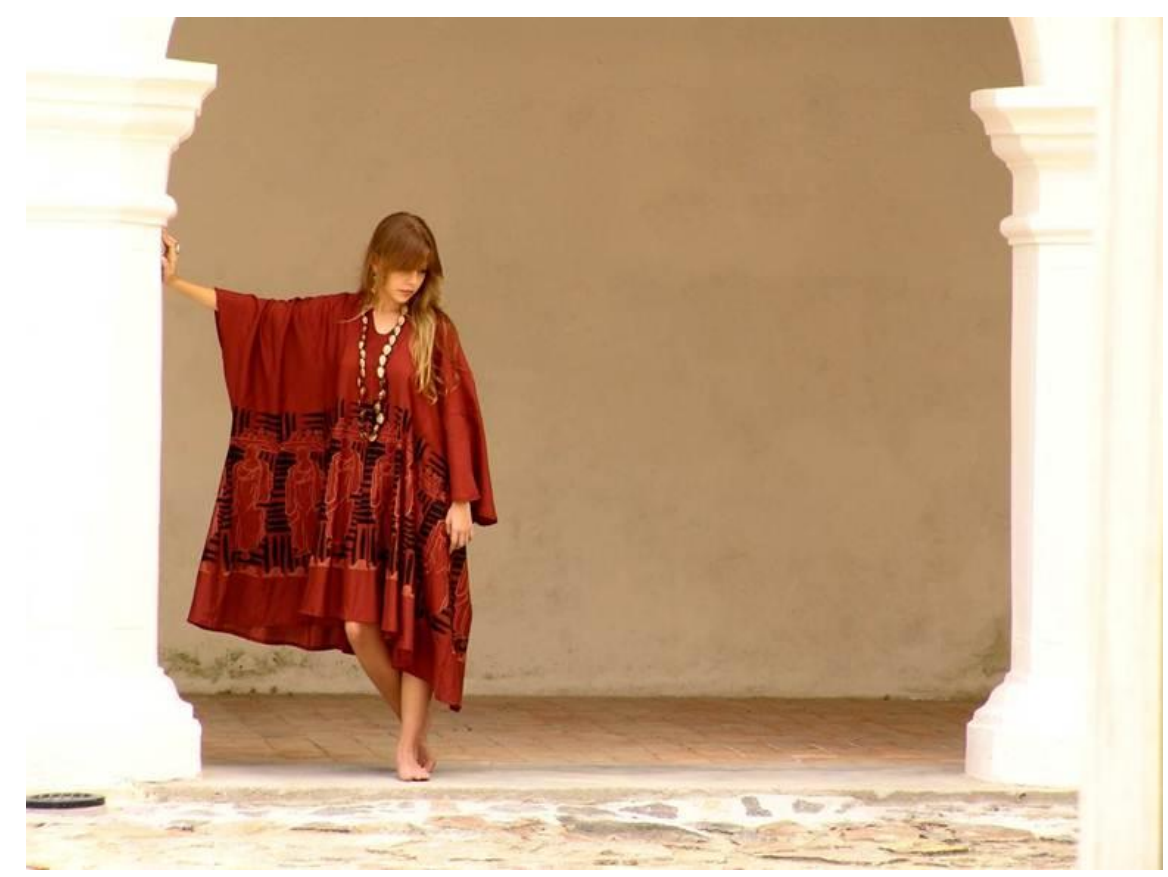

Fonte: foto Nemo Sampaio

http://www.miniweb.com.br/historia/artigos/i_moderna/imagens_debret/debret.h tml;

Às vezes vejo algo e fica registrado, estou sempre atenta e aberta para novos acontecimentos e não existe uma fórmula. Assim foi com a coleção Figuras Rupestres da Bahia para o verão 2009. 
Imagem 5 - Coleção Figura Rupestre da Bahia

\section{Inspirações - Figuras Rupestres da Bahia}
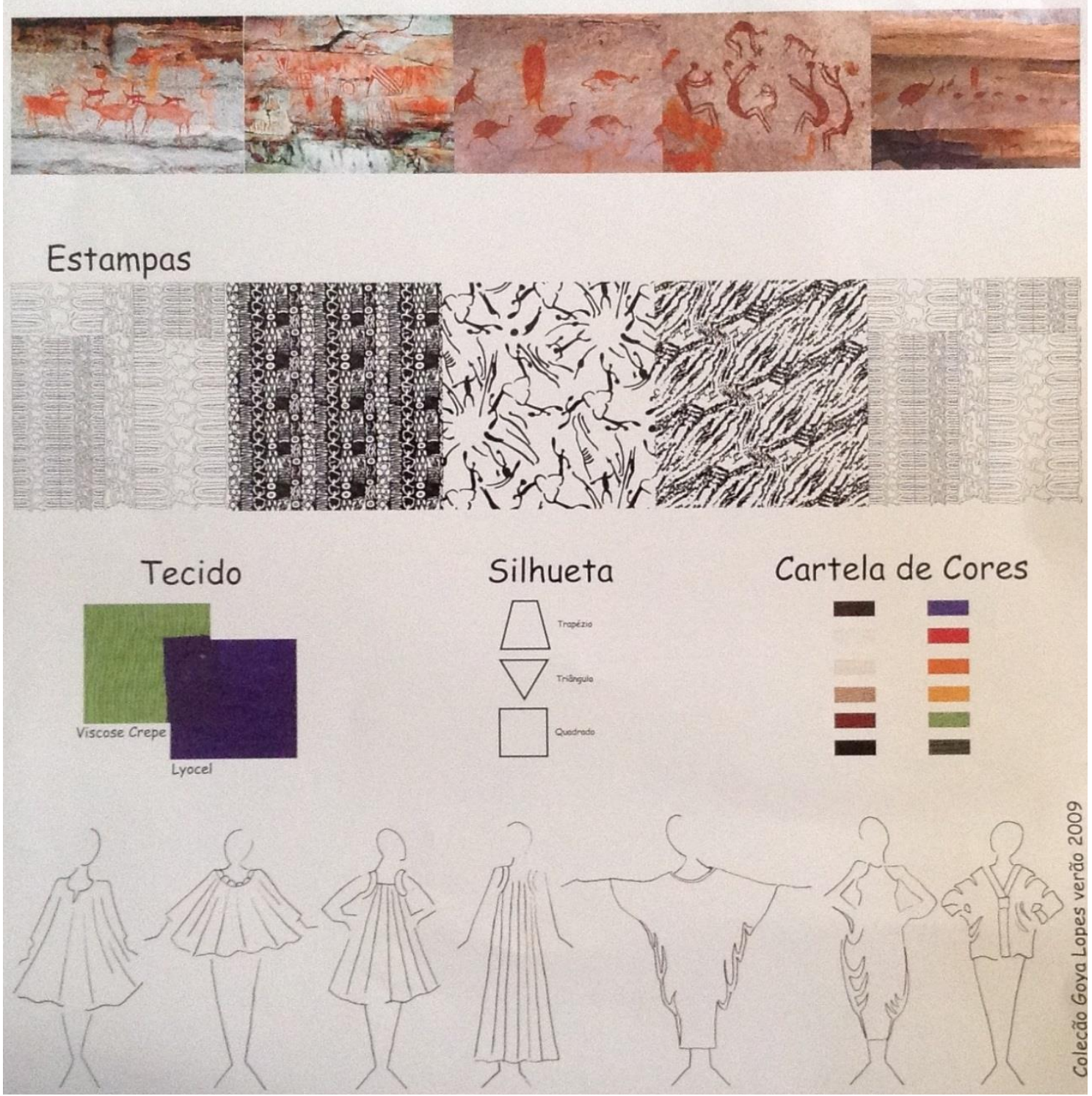

Fonte: acervo da autora.

Já a coleção Provérbios Africanos surgiu depois de ganhar dois livros em tempos próximos: I Provérbi Dell'A Africa-Nera de Giovane Africa Edizoni (2011), e “Owé Provérbios" de Mãe Stella de Oxosi (2007). A minha percepção estava certa: ali era a referência para a nova coleção. Procurei observar cada detalhe dos livros e ampliar a pesquisa no assunto, na busca de aprofundar o conteúdo cada vez mais e transformá-lo em uma coleção. Foram relacionados 12 provérbios, desenhei por meio da simbologia 
brasileira, contando as histórias de cada provérbio de maneira bem figurativa, para que o cliente interagisse.

Imagens 6-Coleção Provérbios: Antiguidade é Posto, Cada Um no seu Quadrado, Tambores e Mel e fel
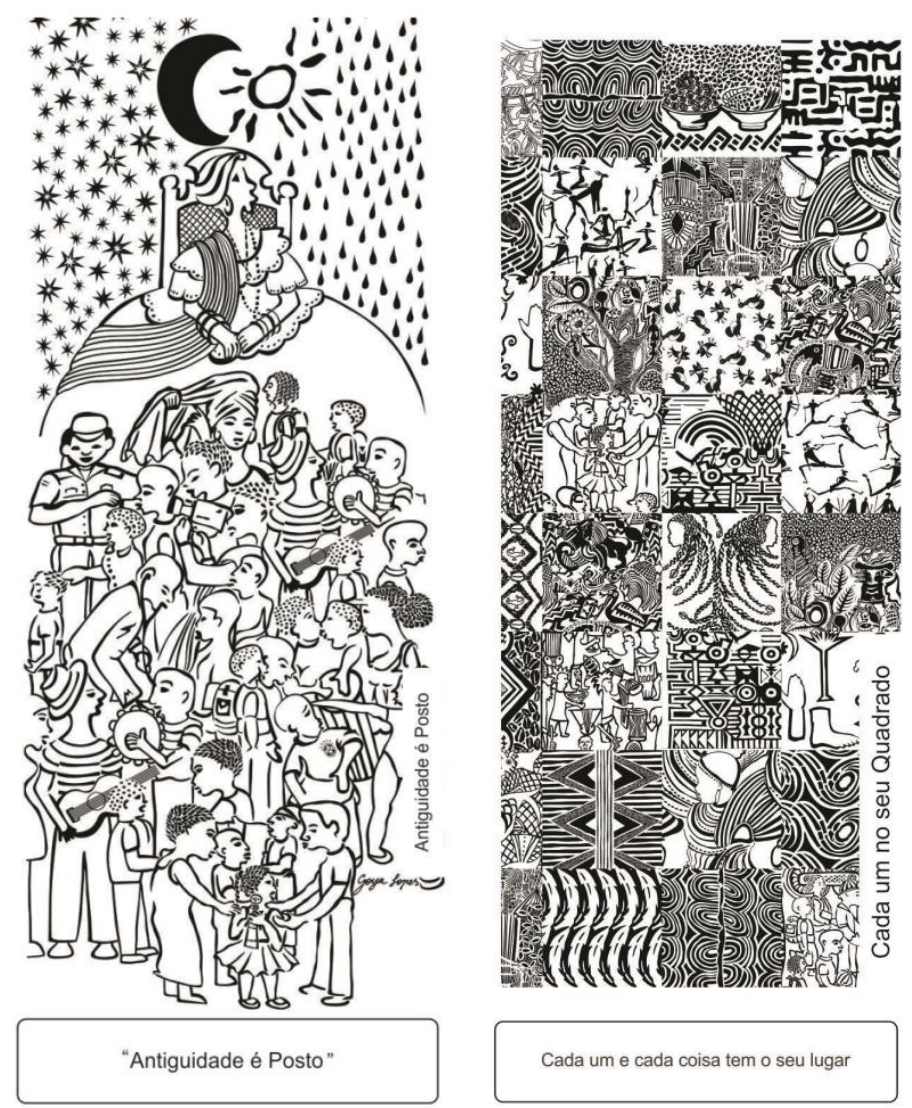

Cada um e cada coisa tem o seu lugar 

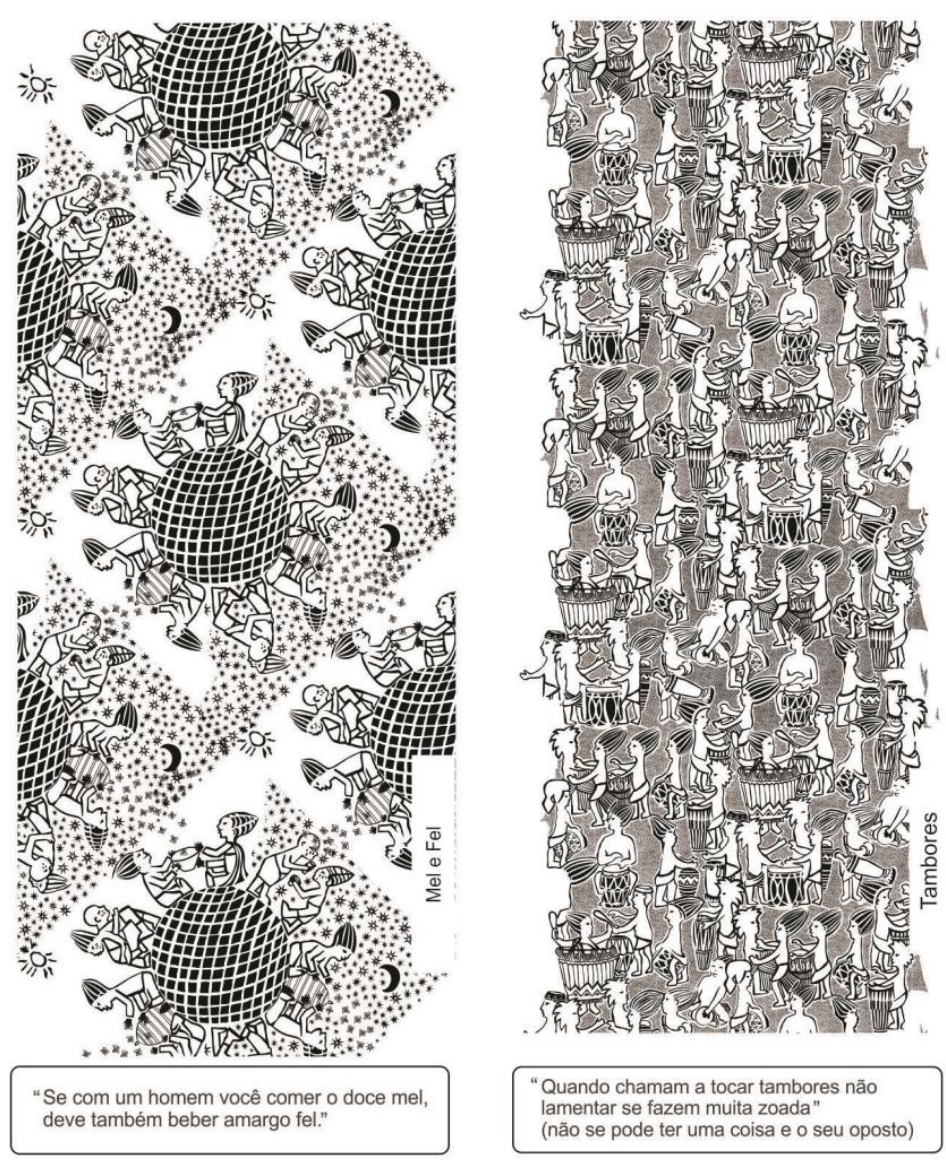

Fonte: acervo da autora

Cada vez mais o design foi aumentando a força do ponto de vista criativo, para que não se prendesse ao regionalismo, à mercê de poucas respostas financeiras, pois, a nossa força deveria estar em condição de se tornar universalmente unida aos demais criadores, pronta para enfrentar um mercado competitivo. No projeto inicial da Didara, a finalidade era de a marca ser uma vertente da moda afro-brasileira, o mercado sonhava com um produto com identidade cultural, vinculado à matriz africana e/ou afrobrasileira. Esse nicho de mercado atenderia o segmento B2B, consumidor final, de afrobrasileiros e todo aquele que valorizasse a cultura brasileira. Foi necessário um esforço e paciência para alcançar equilíbrio. A memória que guardo comigo me obriga a buscar sempre novos conhecimentos, ganhando novas perspectivas e formas que brotam a partir da espontaneidade e imaginação do público alvo, construindo e posicionando a marca a cada dia com o cliente e o deixando atento aos nossos passos. Ao longo desses anos, tive algumas lojas, em Salvador: Centro Antigo e Aeroporto e em Porto Seguro. 
Forneci para algumas lojas multimarcas de Praia do Forte, Sauipe, Arraial d'Ajuda, Trancoso, São Paulo e Brasília, fizemos exportação para Itália, Espanha e EUA. Em 1993 ganhei o $7^{\circ}$ prêmio do Museu da Casa Brasileira nas categorias têxteis e revestimentos, ao lado da ANA-Arte Nativa Aplicada e foi uma grande satisfação saber que a marca começava a ter visibilidade no Brasil. Segundo Adélia Borges:

"A Didara e a Arte Nativa Aplicada fazem uma reinterpretação de nossas multifacetadas influências para chegar a um trabalho decididamente contemporâneo. Pela consistência do conteúdo e da forma, os tecidos de ambas passam ao largo do modismo e têm um lugar garantido no futuro (BORGES, 1995)".

Sempre mantive o lado artístico em atividade, criando uma sinergia Arte-Moda, como também participando de exposições, cenários, ambientações e figurinos. Durante dez anos, fiz figurino para Jimmy Cliff, vesti também outros, como Moraes Moreira, Gilberto Gil, Virgínia Rodrigues, Araketu, Sônia Braga, Angelique Kidjo, entre outros. A ambientação de alguns espaços com panôs ampliou o meu mercado para hospitalidade ${ }^{3}$ : hotéis do Complexo Sauipe; Hotel Pestana, Restaurante Senac Pelourinho; Hospital como o CAP-Centro de Atendimento Pediátrico do grupo Aliança com um painel na recepção e, nos quartos e corredores, mosaicos para uma melhor higienização e uma gruta pintada à mão, além dos uniformes das técnicas, enfermeiras e o estofamento dos quartos. Também atuei na Fundação Palmares, Fundação Ford em Nova Iorque no setor de mídia e artes; no salão do Itamaraty aonde o presidente Fernando Henrique Cardoso recebeu as Missões Especiais Estrangeiras na sua Primeira posse e na ambientação na casa do Benim em Salvador. Em 2002 recebi da Câmara Municipal de Salvador a Comenda Maria Quitéria, homenagem às mulheres baianas que se destacam por seu trabalho.

Ministrei oficinas e workshops na Bahia, São Paulo, Goiás, Distrito Federal, fui palestrante na Bahia, Rio grande do Sul, São Paulo, Paraná, Roraima, Pernambuco, Minas Gerais, Itália e EUA; fui professora de Design aplicada à Moda 1 - Estamparia da UNIFACS-Universidade de Salvador de 2000 e 2001- no Curso de Gestão de Moda. Participei de desfiles em Nova York, Chicago, Fortaleza e Salvador.

\footnotetext{
3 Hospitalidade constituir a estrutura e a rede de serviços que visa atender a demanda turística e a demanda de lazer e de eventos, especialmente nos segmentos de hospedagem e gastronomia. Os principais estabelecimentos que atendem a esta demanda seriam os hotéis, as pousadas, os restaurantes e os centros de convenções.

http://qiprofissional.com.br/blog/hospitalidade-mais-que-um-conceito-um-diferencial/
} 
Imagens 7-Desfile: Sarau do Brown e Dragão Fashion
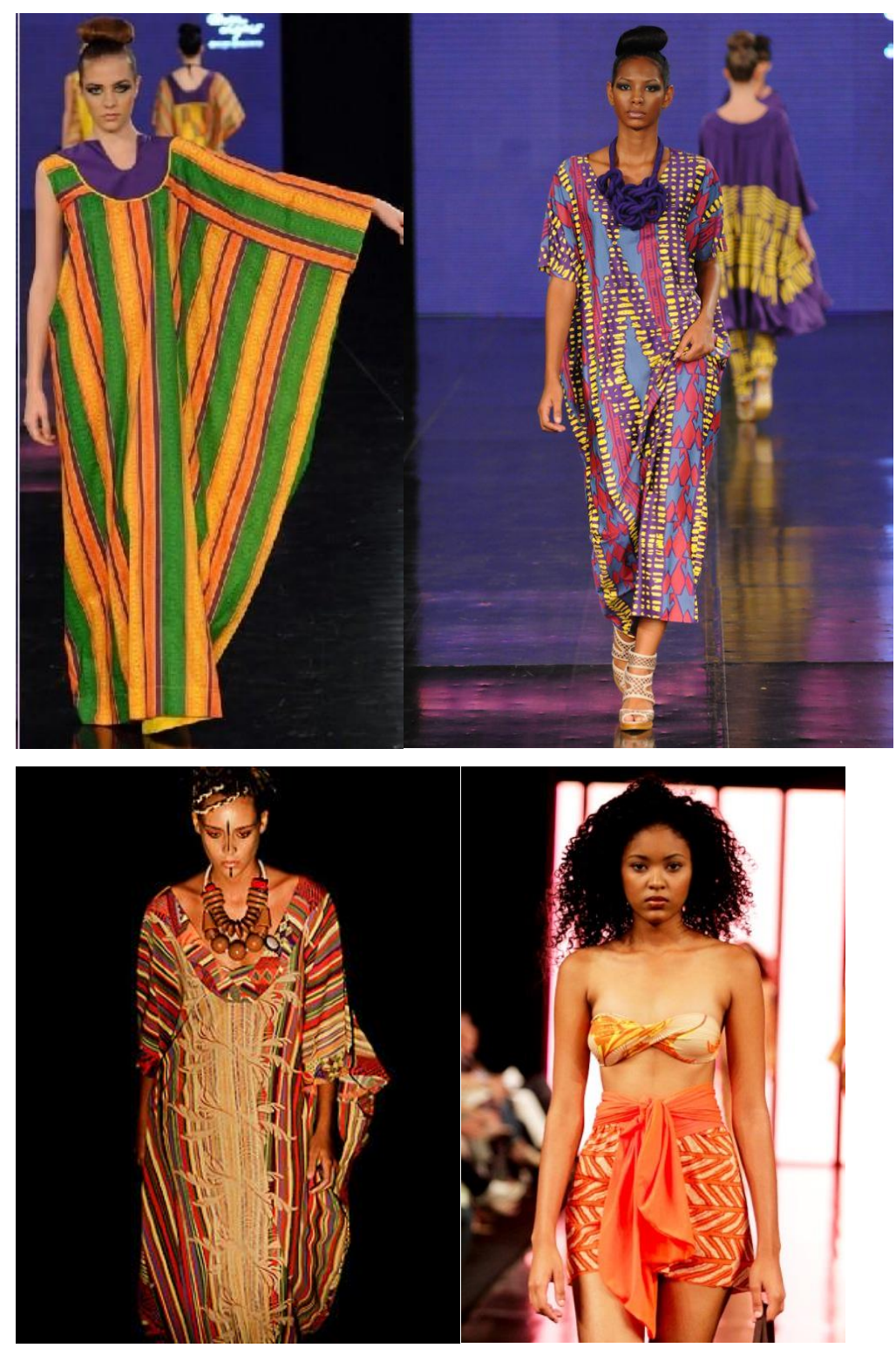

Fonte: acervo da autora.

Atuei como diretora na ABDESIGN-Associação Bahia Design e SINDVESTSindicato do Vestuário de Salvador. Em 2010 lancei o livro Imagens da Diáspora, criado em parceria com o historiador Gustavo Falcón da editora Solisluna, com trinta estampas e com referências à diáspora africana no Brasil.

Durante a minha trajetória, sempre procurei alinhar o meu discurso com a minha prática, fato que vem sendo percebido por pesquisadores da área de moda e cultura. Segundo Claudia Trindade, na sua dissertação: 
"Verifico a partir da análise da trajetória de Goya que suas ações são fortalecidas por seu próprio discurso, bem como pelas narrativas construídas por outros profissionais que exaltam o seu trabalho como uma manifestação cultural. Goya pode ser considerada mais uma voz autorizada que adquiriu competência para referenciar a cultura afro-brasileira através da moda. (TRINDADE, 2013, p.55 de 106).”

Para reforçar essa abordagem de voz autorizada, a pesquisadora cita Bourdieu (1994, p.157),

"a língua é feita para comunicar, portanto para ser compreendida, decifrada. O universo social é um sistema de trocas simbólicas e a ação social um ato de comunicação". O autor também discute questões de como o discurso através da performance e competência produzem ou alteram as interações sociais. $\mathrm{O}$ autor ressalta que "a competência implica o poder de impor a recepção". (BOURDIEU, 1994, p.157).

Segundo a autora, essa relação prevê não apenas um emissor legítimo para recebê-la. Nesse caso, o discurso possui um valor dominante sobre aquele que é dominado. "Esses conceitos são relevantes para um melhor entendimento da questão da autoridade dos autores e como, através de sua competência, eles se transformam em vozes autorizadas para um público receptor das mensagens." (TRINDADE, 2013, p.55 de 106) pdf.

Vale mencionar que fui convidada, em 2009, para fazer parte do GT-Grupo de Trabalho de formação do Colegiado Setorial de Moda, com caráter mobilizador e reflexivo, vinculado ao Conselho Nacional de Política Cultural (CNPC) do MINCMinistério da Cultura. Foi realizada a pré-conferência de moda a fim de refletir, discutir e propor novos caminhos para a construção de políticas setoriais do MINC para o setor de moda e o fortalecimento da identidade cultural da moda brasileira. Os debates foram aprofundados no primeiro seminário de moda, realizado em setembro de 2010, na cidade de Salvador. Foram convidados profissionais dos eixos criativos, produtivos e institucional entre os quais fui eleita como membro representante do eixo criativo para o primeiro Colegiado Setorial de moda. Fui reeleita para o exercício do segundo Colegiado Setorial de Moda encerrando em 2015 as minhas atividades.

O I Seminário Nacional de Moda e Cultura 2010 serviu também para colocar em contato designers e estilistas da moda afro-brasileira (Fátima Negrann, Makota Kizamdembu e outros). Em 2011, foi formado um GT de Moda afro-brasileira Fátima Negrann-RJ, Makota Kizamdembu- MG, Edson Luiz - SP, Graça Santos - DF e Goya 
Lopes -BA) sendo que atualmente fundamos a ANAMAB-Associação Nacional da Moda Afro-Brasileira ${ }^{4}$, na qual eu criei a marca.

Imagem 8-Marca ANAMAB

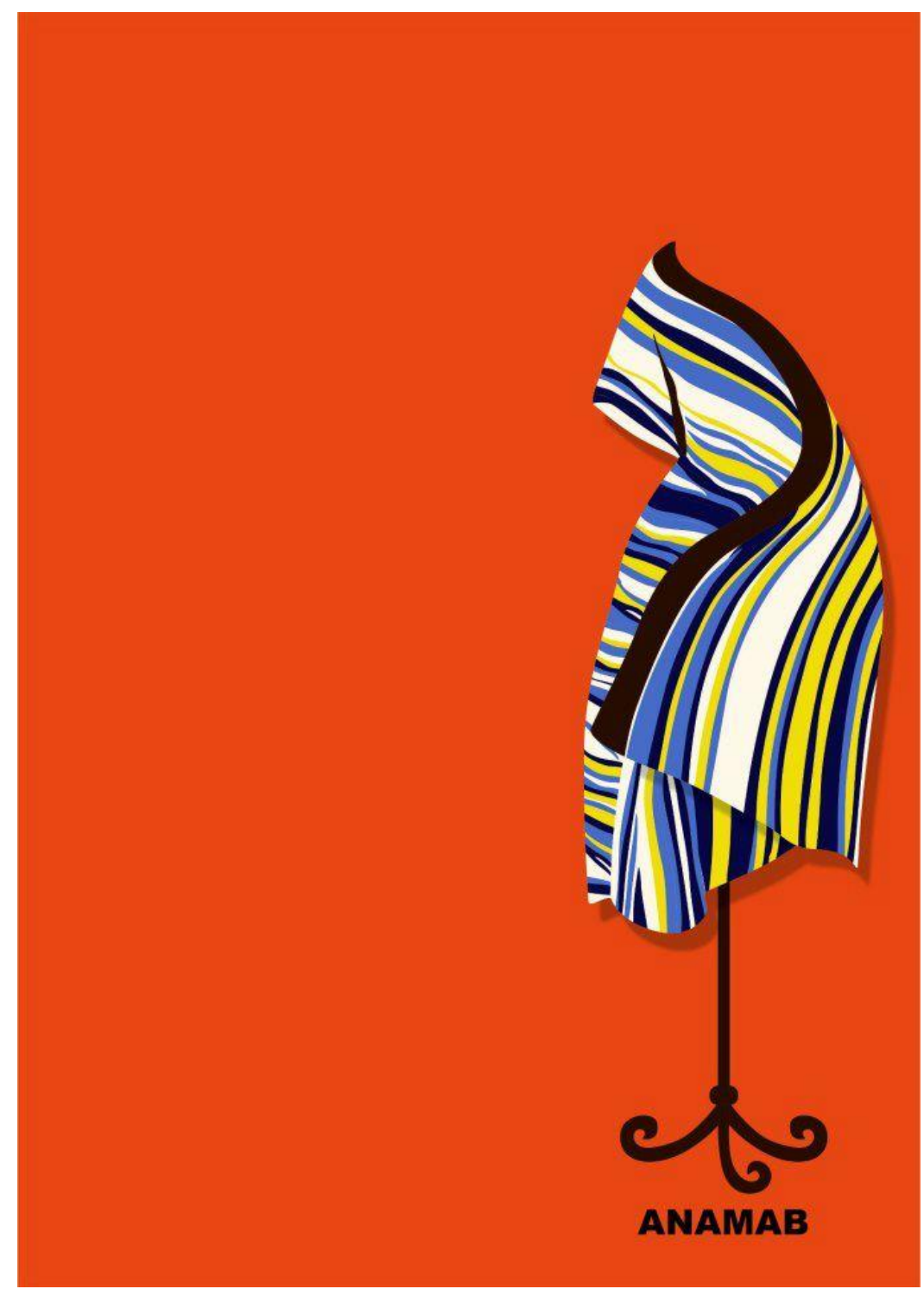

Fonte: acervo da autora

4 A logomarca da ANAMAB-Incorpora elementos com a referência no Pano da Costa ( ALAKA) produzido em tear manual, é formado por tiras, que são depois costuradas. Valoriza os saberes e fazeres tem uma profunda conotação sócio religiosa, atua em diversas situações e desempenha papéis significativos. Atravessou o Attântico e é até hoje uma grande referência esse pedaço simbólico de tecido. Elemento fácil para se fazer uma releitura. O manequim simboliza a moda Goya Lopes. 
No momento, estamos planejando um evento e mapeando todos os criadores da moda afro-brasileira e discutindo as ações empreendedoras no Brasil. Segundo Patrícia Harger e Marivânia Conceição de Araujo:

\begin{abstract}
As manifestações estéticas da moda afro-brasileira são materializadas através de elementos associados à vida dos negros, podendo estar ligados aos antepassados e às cerimônias religiosas ou a outros costumes que envolvem o uso de turbantes ou panos da costa. Porém, a moda afro-brasileira não faz referência apenas à África. Ela utiliza também elementos da cultura brasileira, desse modo, se apropria de elementos de diferentes culturas existentes no Brasil, como indígena, portuguesa, inglesa e africana e cria através de arranjos próprios sua identidade. Portanto, moda afro-brasileira nasce da mistura da cultura brasileira com africana (HERGER; ARAUJO, 2015. p.3).
\end{abstract}

Em 2012 foi criada a Secretaria de Economia Criativa (SEC), articuladora das produções criativas funcionais, sendo uma delas foi a Moda. Segundo o Plano da SEC, Diretrizes e Ações 2011 a 2014, p.24

"A economia criativa é, portanto, a economia do intangível, do simbólico. Ela se alimenta dos talentos criativos, que se organizam individualmente ou coletivamente para produzir bens e serviços criativos. Por se caracterizar pela abundância e não pela escassez, a nova economia possui dinâmica própria e, por isso desconcerta os modelos econômicos tradicionais, pois seus novos modelos de negócio ainda se encontram em construção, carecendo de marcos legais e de bases conceituais consentâneas com os novos tempos".

Com base no arranjo produtivo da música, apresentado na figura 3, no Plano da SEC-Secretaria de Economia Criativa, p. 25, busquei fazer, no segundo mandato do Colegiado Setorial de Moda, o arranjo produtivo da moda, colocando, nessa dinâmica, diversos profissionais envolvidos que executam suas ações para se chegar a uma finalização. Dessa maneira, conseguimos enxergar, na figura 1, o quanto o setor de moda pode ser criativo, transversal e interativo. 
Figura 1

INTERFACES DOS SETORES DA MODA

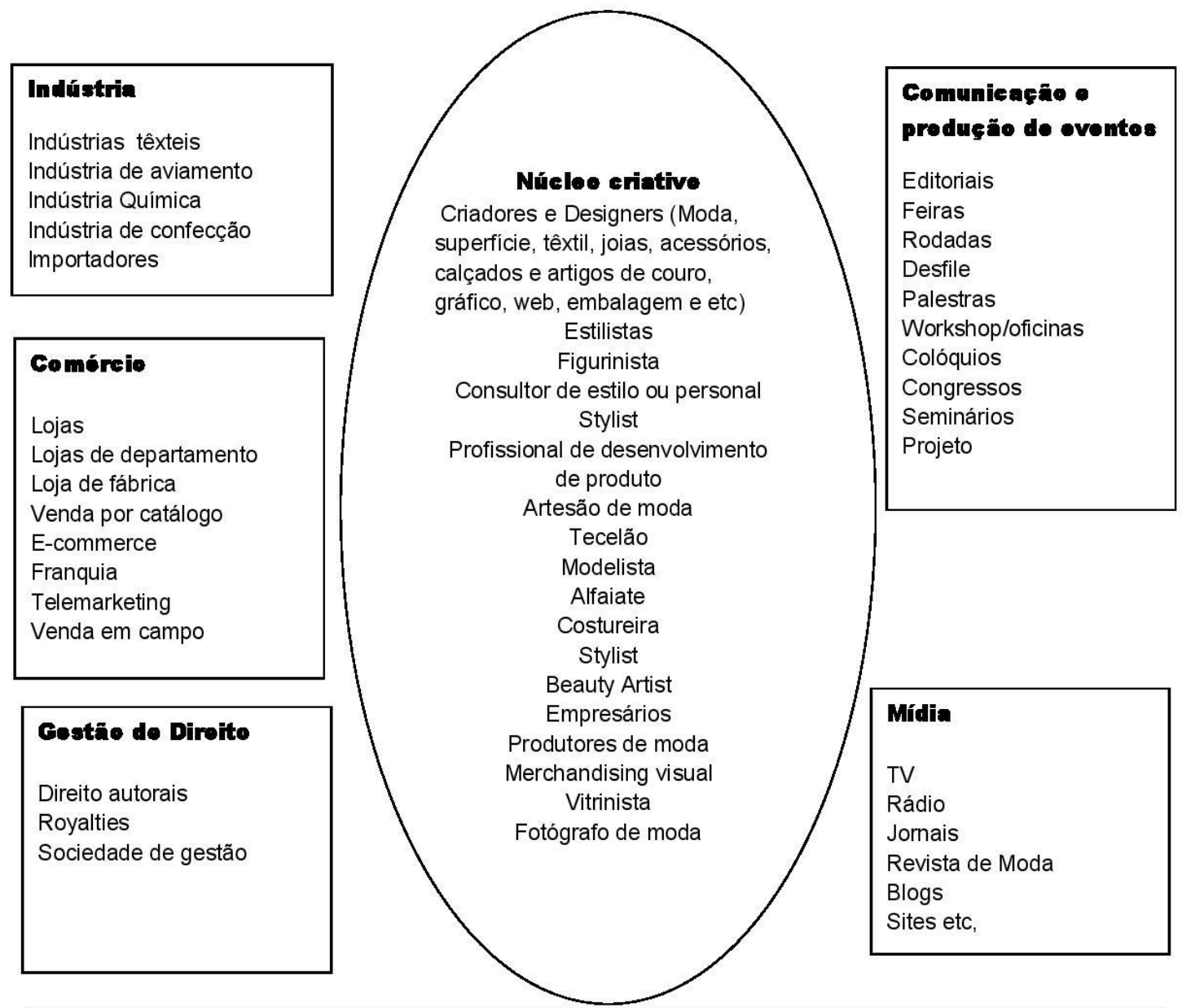

Fornecedores

Maquinas e equipamentos, fiação, industria têxtil, industria de máquina, beneficiamentos, colorista, serigrafia, estamparia digital, jornalista de moda, estúdio fotográfico, passarela, diretor de desfile, relações pública, agência de modelo, iluminação, assessoria de imprensa, agência de publicidade, manutenção de sites, serviço áudio visual, DJ, prognóstico de tendência, pesquisa acadêmica, Inmetro etc.

\begin{tabular}{|l|}
\hline Instituişões Culturais \\
Institutos \\
Fundações \\
Centro de moda \\
Agencia de fomento \\
Museus \\
Inttittuişöe / Oruãos \\
Federações e sistema S - SEBRAE \\
MINC - Setorial de moda \\
Secretaria da Cultura estadual \\
MIDIC - Apex Brasil \\
Bancos de Fomento
\end{tabular}

\begin{tabular}{|l|}
\hline Contros Educacienais \\
Escolas regulares \\
Escolas Técnicas \\
Universidades \\
Escola de moda \\
\end{tabular}

\section{Asseciaçöe}

Profissionais

ABIT

ABEST

ABRAVEST

ANAMAB

Associações

Sindicatos

Cooperativas

Fonte: acervo da autora. 
No atual cenário brasileiro, foi fundamental repensar os negócios de uma nova maneira, novos modelos de negócios criativos e sustentáveis, arranjos produtivos e comercialização. A estratégia foi uma nova empresa e marca: Goya Lopes Design Brasileiro, pautada numa riqueza construída ao longo de trinta anos, de um capital de relacionamento e um acervo de mais de mil criações, desenhos e estampas. Ampliar a carteira de clientes foi essencial, criei a identidade para o INCTI - Instituto Nacional da Ciência e Tecnologia da Inclusão - UNB - Universidade de Brasília - Encontro dos Saberes. Antes só fazia criações de design de superfície para a minha empresa, com algumas exceções, como: Loja Exclusiv em 1997- SP, marca Neon para o desfile SPFW- São Paulo Fashion Week verão 2007. Com essa nova proposta, a marca Goya Lopes Design Brasileiro, fez parceria e prestou serviços para Tok\&Stok, Boticário, Bali Blue sendo esta parceria mais ampla, pois além de criar a coleção das cangas Bali Blue By Goya Lopes, elas são vendidas na nossa loja no Pelourinho.

Imagem 10-Criações: Sacola Tok\&Stok, sacola Boticário e Canga Bali Blue

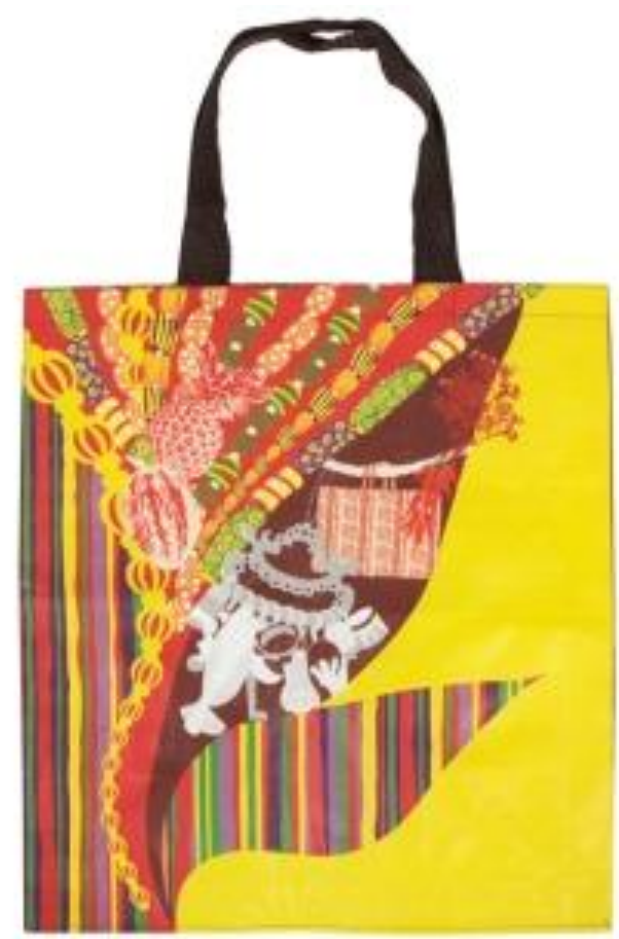



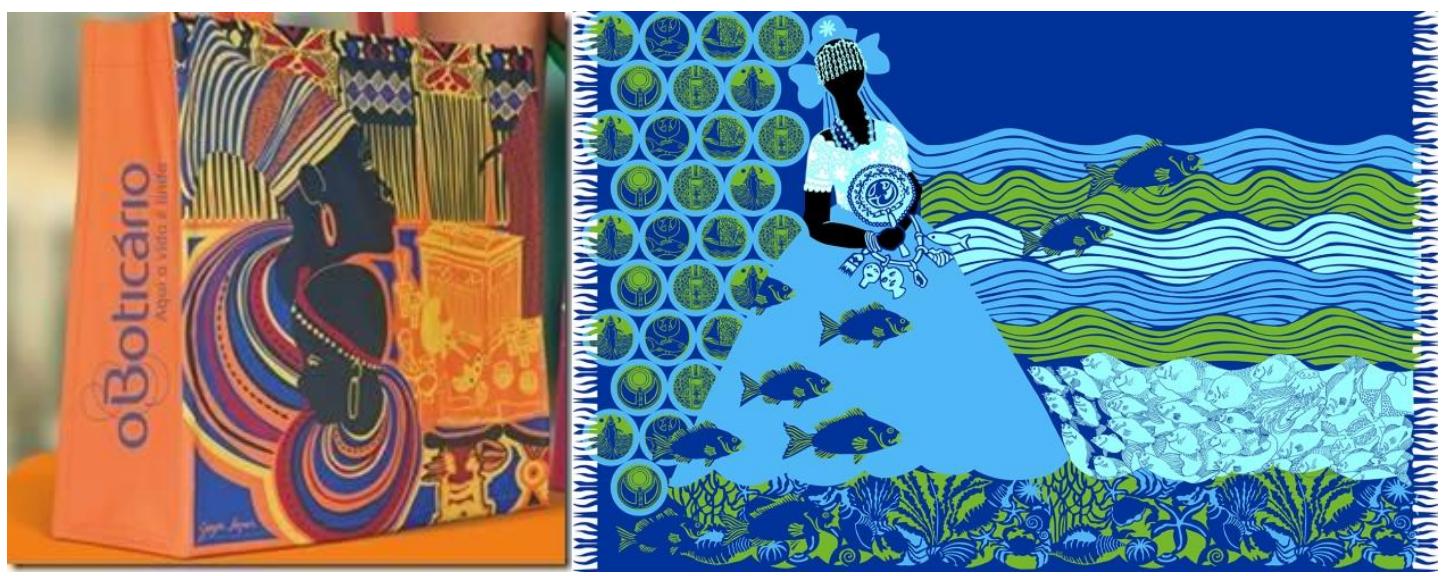

Fonte: acervo da autora.

A Goya Lopes Design Brasileiro amplia com a implementação da sua loja virtual, www.goyalopes.com.br, ações de design de superfície e busca referência na identidade e diversidade brasileira; ela é um grande guarda-chuva que abriga o nicho afro-brasileiro, que fica cada vez mais original nas suas criações e conteúdos. Ao longo da minha carreira artística e profissional de design construí uma plataforma sedimentada, caracterizada pela identidade, diferenciação e versatilidade, criando um trabalho autoral, que a cada dia se envolve nas mudanças e na dinâmica do mercado que oferece diversas possibilidades e demandam uma constante inovação e experimentos. 
Imagens 11-Loja virtual
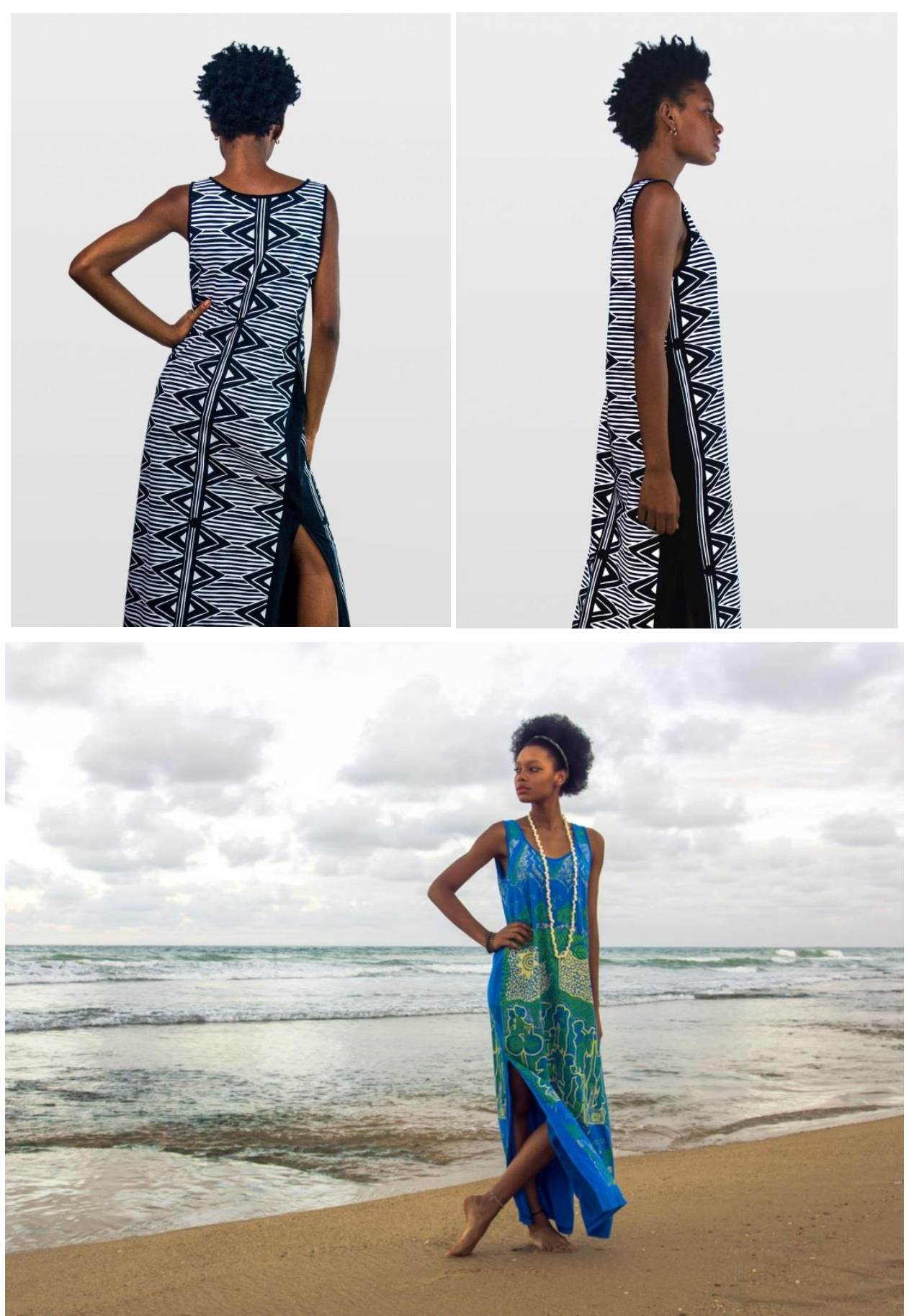

Fonte: Acervo autora 


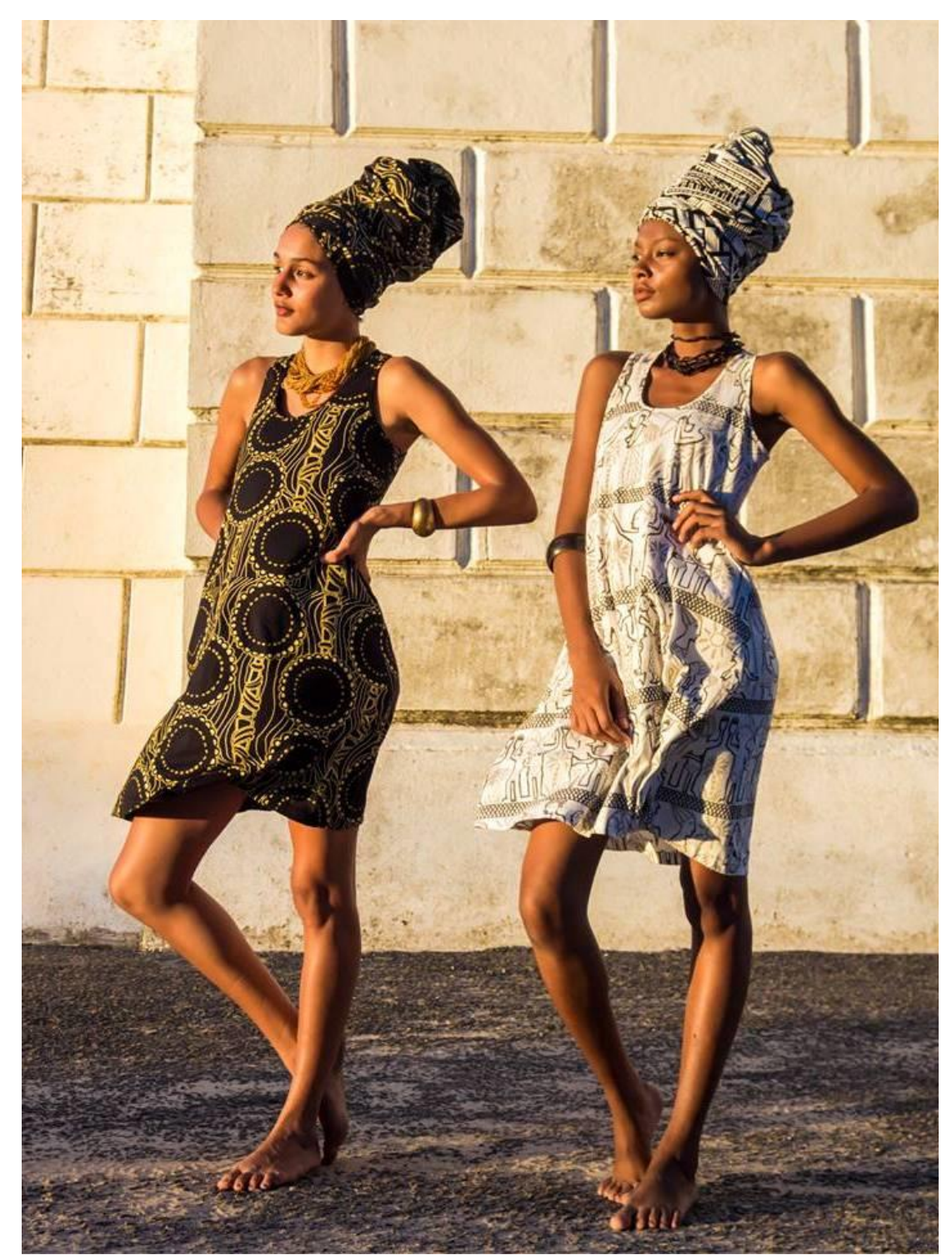

Fonte: Foto Kin Guerra

Artigo recebido em Maio de 2016. Aprovado em Junho de 2016 DOI:http://dx.doi.org/105965/1982615x09182016021 


\section{Referências}

BORGES, Adélia. O Brasil Estampado SP. Revista Exame Elemento de Estilo, São Paulo, no 9 - edição 125, p. 129, 1995.

BURDEK, Bernhard E. Diseño: Historia, teoría y práctica del diseño industrial. Barcelona: Gustavo Gili, 1994. Estágio de artista, História do Design, n.6. Disponível em http://www.estagiodeartista.pro.br/artedu/histodesign/6_novodesign.htm, acesso em maio, 2016.

HARGER, Patrícia; ARAÚJO, Marivânia Conceição de. Estilista da Moda Afro Brasileira: A identidade que se Traduz em Roupa. In: VII Congresso Internacional de História, XXXV Encuentro de Geohistoria Regional, XX Semana de História 2015, Maringá-PR.

LUZ, Neira Garcia. Estampas na tecelagem brasileira: da origem à originalidade. Tese (Doutorado em Arquitetura e Urbanismo) - Faculdade de Arquitetura e Urbanismo, Universidade de São Paulo, São Paulo, 2012. Disponível em: www.teses.usp.br/teses/disponiveis/16/16133/tde-28112012.../tese_luz_original.pdf, acesso em maio, 2016.

MACHADO, Luís. QI Profissional, Hospitalidade, mais que um conceito, um diferencial, $\quad$ p.1, 24/09/2012, disponível em: http://qiprofissional.com.br/blog/hospitalidade-mais-que-um-conceito-um-diferencial/. acesso em maio 2016.

Plano da Secretaria da Economia Criativa: políticas, diretrizes e ações, 2011-2014, Brasília, Ministério da Cultura, 2011 - $1^{\circ}$ Edição REVISADA - p.24.

TRINDADE, Cláudia. Goya Lopes, a contadora de histórias: Arte, Moda, Desenho e Design como lugares de memória. 2013. 106f. Dissertação (Mestrado em Desenho Cultura e Interatividade) - Departamento de Letras e Artes-Programa de Pós Graduação em Desenho, Cultura e Interatividade, - Universidade Estadual de Feira de SantanaUEFS-Feira de Santana, Feira de Santana, Bahia, 2013. 